\title{
DETEKSI DINI PENCAPAIAN PERKEMBANGAN ANAK USIA 3-4 TAHUN BERDASARKAN STANDAR NASIONAL PENDIDIKAN ANAK USIA DINI
}

\author{
Dahlia Patiung \\ Jurusan Pendidikan Islam Anak Usia Dini \\ Fakultas Tarbiyah dan Keguruan, UIN Alauddin Makassar \\ E-mail: dahliapatiung@yahoo.co.id \\ Ismawati \\ Jurusan Pendidikan Islam Anak Usia Dini \\ Fakultas Tarbiyah dan Keguruan, UIN Alauddin Makassar \\ E-mail: ismaindar27@gmail.com \\ Herawati \\ Jurusan Pendidikan Islam Anak Usia Dini \\ Fakultas Tarbiyah dan Keguruan, UIN Alauddin Makassar \\ E-mail: herawatii7516@gmail.com \\ Suci Ramadani \\ Jurusan Pendidikan Islam Anak Usia Dini \\ Fakultas Tarbiyah dan Keguruan, UIN Alauddin Makassar \\ E-mail: sucirmdni99@gmail.com
}

\begin{abstract}
Abstrak
Penelitian ini bertujuan untuk mengetahui tingkat pencapaian pada aspek perkembangan anak usia 3-4 tahun berdasarkan standar pendidikan nasional pendidikan anak usia dini (PAUD) dan memberikan stimulus awal terhadap hambatan yang dialami anak dalam indikator pencapaian pada aspek perkembanagan anak usia dini. Penelitian ini merupakan penelitian kualitatif jenis deskriptif dengan subjek penelitian tiga anak. Data dikumpulkan menggunakan observasi, wawancara dan beberapa rangkaian pemberian stimulus untuk mendukung anak dalam memunculkan respon terhadap indikator pencapaian perkembangan yang hendak dicapai mulai dari aspek perkembangan nilai agama dan moral, fisik-motorik, kognitif, bahasa, sosial-emosional, hingga pada aspek perkembangan seni. Data dianalisis menggunakan analisis deskriptif. Hasil penelitian menunjukkan bahwa ketiga subjek IJ, RA dan SY sudah mampu melakukan beberapa indikator pencapaian yang terdapat dari beberapa aspek perkembangan anak usia dini. Implikasi penelitian ini hendaknya diberikan stimulus secara simultan pada indikator yang belum tercapai. Pola asuh dan pemberian stimulus dari keluarga dan lingkungan sekitar.
\end{abstract}

Kata Kunci: Anak Usia Dini, Deteksi Dini, Pencapaian Perkembangan 


\begin{abstract}
This study aimed at determining the extent of the achievement level of developmental aspects of 3-4 years old children based on national education standards for early childhood education (PAUD) and providing an initial stimulus towards the obstacles experienced by children in achievement indicators of early childhood developmental aspects. This research was a descriptive qualitative research with three research subjects. The data were collected using observations, interviews and a series of stimulus programs to support children in generating responses towards developmental achievements indicators to be achieved starting from the development of religious and moral aspects, physical-motoric, cognitive, language, social-emotional values, until the art development aspects. The summarized data was analyzed by using descriptive analysis. The results of the study showed that the three subjects (IJ, RA, and SY) were able to perform several achievement indicators contained in several aspects of early childhood development. The implications of this study should be given a stimulus simultaneously on indicators that have not been achieved. Foster care and stimulus from the family and the surrounding environment.
\end{abstract}

Keywords: Early Detection, Early Childhood, Developmental Achievement

\title{
PENDAHULUAN
}

Whaley dan Wong (Supartini, 2004: 49) mengemukakan pertumbuhan sebagai suatu peningkatan jumlah dan ukuran, sedangkan perkembangan menitikberatkan pada perubahan yang terjadi secara bertahap dari tingkat yang paling rendah ke tingkat yang paling tinggi dan kompleks melalui proses naturasi dan pembelajaran. Menurut Syamsu dalam (Susanto, 2011: 19) perkembangan adalah perubahanperubahan yang dialami oleh individu atau organisme menuju tingkat kedewasaanya, atau kematangan (Maruration) yang berlangsung secara sistematis, progresif dan berkesinambungan, baik menyangkut fisik maupun psikis.

Perkembangan peserta didik merupakan sebuah perubahan secara bertahap dalam kemampuan, emosi, dan keterampilan yang terus berlangsung hingga mencapai usia rentang usia 0-6 tahun atau pada masa ini sering disebut dengan masa the golden age atau masa keemasan sebab pada usia ini terjadi perkembangan yang sangat menakjubkan dan terbaik pada usia dini. Pada masa ini, seorang anak mengalami tumbuh kembang yang sangat luar biasa, baik dari segi fisik, motorik, emosi, kognitif, maupun psikososial (Indrijati, 2016: 26).

Menurut National Association for the Education Young Children (NAEYC) menyatakan bahwa anak usia dini atau early childhood merupakan anak yang berada pada usia 0-8 tahun. Pada masa itu merupakan proses pertumbuhan dan perkembangan berbagai aspek dalam rentang kehidupan manusia. Proses pembelajaran terhadap anak harus memperhatikan karakteristik yang dimiliki dalam tahap perkembangan berbagai aspek dalam rentang kehidupan manusia. Proses 
pembelajaran terhadap anak harus memerhatikan karakteristik yang dimiliki dalam tahap perkembangan anak.

Perkembangan anak usia dini mencakup berbagai aspek. Secara umum, perkembangan anak usia dini mencakup perkembangan fisik, sosial, emosi, dan kognitif. Namun beberapa ahli mengembangkan menjadi aspek-aspek perkembangan lebih terperinci. Di dalam Peraturan Menteri Pendidikan dan Kebudayaan Nomor 146 Tahun 2014 tentang Kurikulum 2013 Pendidikan Anak Usia Dini pada Pasal 5 dinyatakan, bahwa aspek-aspek pengembangan dalam kurikulum PAUD mencakup nilai agama, nilai moral, fisik-motorik, kognitif, bahasa, sosialemosional, dan seni (Sit, 2017: 9).

Pada perkembangan anak usia dini memiliki tingkat pencapaian yang berbedabeda sesuai tingkatan usia anak. Begitu pula bagi anak yang berusia 3-4 tahun memiliki perbedaan standar tingkat pencapaian perkembangan dibanding usia di bawah atau di atasnya. Tingkatan pencapaian perkembangan digunakan untuk melihat sejauh mana perkembangan anak atau anak berkembang sesuai tingkatan usianya atau belum.

Tingkat pencapaian perkembangan itu secara rinci telah tertuang dalam Peraturan Menteri Pendidikan dan Kebudayaan Republik Indonesia Nomor 137 Tahun 2014 Tentang Standar Nasional Pendidikan Anak Usia Dini. Dalam peraturan itu berisi tentang Tingkat Pencapaian Perkembangan Anak mulai aspek perkembangan nilai agama-moral, fisik-motorik, kognitif, bahasa, sosial-emosional, dan seni.

Deteksi dini merupakan upaya penjaringan yang dilaksanakan secara komprehensif untuk menemukan penyimpangan tumbuh kembang dan mengetahui serta mengenal faktor resiko (fisik, biomedik, psikososial) pada balita, yang disebut juga anak usia dini (Tim Dirjen Pembinaan Kesmas, 1997). (Tin Suharmini, dkk: 2009)

Pentingnya melakukan penelitian ini agar para pendidik atau para orang tua mengetahui tingkat pencapaian perkembangan anak. Sehingga apabila dalam tingkat pencapaian perkembangan anaknya ada yang belum berkembang atau ada penyimpangan, maka orang tuanya bisa langsung memberikan stimulasi, penyembuhan serta pemulihan sesuai dengan penyimpangan apa yang dialami anak. Melalui jurnal ini peneliti bermaksud untuk memberikan gambaran tentang tingkat pencapaian perkembangan anak pada usia 3-4 tahun serta stimulasi apa yang diberikan pada anak.

\section{METODE PENELITIAN}

Penelitian ini merupakan penelitian kualitiatif jenis deskriptif dengan subjek penelitian tiga anak, yakni IJ (usia 3 tahun 7 bulan), RA (Usia 3 tahun 4 bulan), dan SY (Usia 3 tahun 5 bulan). Subjek dipilih dengan kriteria: (1) anak sudah dapat 
mengikuti instruksi; (2) berada pada rentang usia 3-4 tahun; (3) orang tua menerima dengan hangat pada penelitian ini; dan (4) mudah dijangkau oleh peneliti.

Data dikumpulkan menggunakan observasi, wawancara dan beberapa rangkaian stimulus untuk mendukung munculnya respon pencapaian perkembangan yang hendak diukur berdasarkan tingkat pencapaian perkembangan anak dalam Peraturan Menteri Pendidikan dan Kebudayaan Republik Indonesia Nomor 137 Tahun 2014 Tentang Standar Nasional Pendidikan Anak Usia Dini. Aspek yang diukur mulai aspek nilai agama-moral, fisik-motorik, kognitif, bahasa, sosialemosional, sampai pada aspek seni. Data yang sudah terkumpul dianalisis menggunakan analisis deskriptif. Uji kredibilitas data terhadap hasil penelitian dilakukan dengan perpanjangan waktu pengamatan dan diskusi dengan teman sejawat.

\section{HASIL PENELITIAN}

\section{Aspek Perkembangan Nilai Agama dan Moral}

Tingkat pencapaian perkembangan dalam aspek perkembangan nilai agama dan moral dapat dilihat dari tiga indikator: (1) mengetahui perilaku yang berlawanan meskipun belum selalu dilakukan seperti pemahaman perilaku-perilaku baik-buruk, benar-salah, sopan-tidak santun; (2) mengetahui arti kasih dan sayang kepada ciptaan Tuhan; dan (3) meniru doa pendek sesuai dengan agamanya.

Berdasarkan hasil penelitian dari tiga subjek, maka didapatkan gambaran perkembangan nilai agama dan moral yang berbeda-beda dari tiap subjek penelitian. Indikator pertama, IJ dan RA sudah mampu mengetahui perilaku yang berlawanan meskipun belum sering dilakukan. Hal ini terlihat ketika IJ dan RA melakukan perilaku baik seperti membuang sampah pada tempatnya. Dan untuk subjek ketiga belum berkembang dengn baik, hal ini terlihat ketika hendak memukul kakaknya lalu ditegur oleh ibunya, sejenak SY menahan tangannya lalu beberapa saat kemudian ia kembali memukul kakaknya.

Pada indikator mengetahui arti kasih dan sayang kepada ciptaan Tuhan, IJ sudah mengetahui, akan tetapi kadang-kadang masih melakukan perbuatan tidak baik kepada ciptaan Tuhan seperti kucing. Sedangkan pada subjek RA dan SY sudah mengetahui bahwa kucing adalah ciptaan Tuhan terlihat ketika RA melihat kucing RA mengelus-elus dan menyayangi kucing dengan tidak menyakitinya begitupun SY memberikan makan kepada kucing yang kelaparan. Adapun indikator dalam hal meniru doa pendek sesuai dengan agamanya. Ketiga subjek sudah mampu melakukan indikator dengan baik. Hal ini terlihat ketika IJ dan RA, mampu menirukan doa pendek meskipun dengan bantuan orang tuannya. Kemudian SY terlihat ketika mulai bisa melafazkan surah Al-Fatihah walaupun belum sesuai dengan tajwid dan makhrajatul hurufnya.

Dari ketiga subjek sudah mampu melakukan semua indikator dengan baik meskipun anak masih diingatkan atau masih dibantu oleh orang tuanya. 
Keberhasilan pertumbuhan dan perkembangan seorang anak dapat dihubungkan dengan perkembangan sikap dan pribadi orangtuanya serta hubungan komunikasi dan role model dalam keluarganya serta stimulasi dan pola asuh yang diberikan orang tua atau keluarganya. Menurut Effendi (1995) keluarga memiliki peranan utama didalam mengasuh anak, di segala norma dan etika yang berlaku didalam lingkungan masyarakat, dan budayanya dapat diteruskan dari orang tua kepada anaknya dari generasi-generasi yang disesuaikan dengan perkembangan masyarakat (Hulukati, 2015 : 271).

Menurut Darajat (Kurnia, 2015), pertumbuhan agama telah muncul ketika anak belum bisa bicara. Sebelum anak belum bisa bicara anak telah dapat melihat dan mendengarkan kata-kata yang sering diucapkan orangtuanya yang semula tidak mendapatkan perhatian dari anak-anak dan tidak mempunyai arti apa-apa, jika sering diucapkan dan terdengar oleh mereka amaka akan menjadi pusat perhatiannya. Demikian juga sikap, mimik, dan situasi, saat orang tua mengucapkan lambat laun akan diamtinya, dan selanjutnya ditirunya. Seperti Shalat (bacaan dan gerakannya), doa-doa pendek, syahadat, dan zikir (Ananda, 2017: 27-28).

Pendidikan moral yang dilaksanakan sejak usia dini bukanlah suatu usaha yang tiada berguna. Moral yang baik berasal dari lingkungan yang bermoral baik, karena lingkungan (baik lingkungan masyarakat, keluarga, maupun sekolah) menjadi sumber belajar bagi anak dalam berperilaku sesuai dengan nilai-nilai yang berlaku. Anak bermoral tidak hadir secara instant. Anak bermoral dihasilkan melalui proses yang dilalui setiap hari dalam pembinaan moral yang baik, seperti membedakan perilaku baik-buruk, benar-salah, sopan-tidak sopan. (Khaironi, 2017: 12).

\section{Aspek Fisik-Motorik}

Ada dua aspek perkembangan fisik-motorik yang harus dicapai yaitu aspek motorik kasar dan aspek motorik halus. Adapun pada aspek motorik kasar terdapat enam indikator yaitu: (1) berlari sambil membawa sesuatu yang ringan (bola); (2) naik-turun tangga atau tempat yang tinggi dengan kaki bergantian; (3) meniti di atas papan yang cukup lebar; (4) melompat turun dari ketinggian kurang lebih $20 \mathrm{~cm}$ (di bawah tinggi lutu anak); (5) meniru gerakan senam sederhana seperti meniru gerakan pohon, kelinci melompat; (6) berdiri dengan satu kaki. Sedangkan pada aspek perkembangan motorik halus dapat dilihat dari empat indikator: (1) menuang air, pasir, atau biji-bijian ke dalam tempat penampung (mangkuk, ember); (2) memasukkan benda kecil ke dalam botol (potongan lidi, kerikil, biji-bijian); (3) meronce benda yang cukup besar; (4) menggunting kertas mengikuti pola garis lurus.

Berdasarkan hasil penelitian dari tiga subjek, maka didapatkan gambaran perkembangan nilai fisik-motorik kasar sebagai berikut yaitu pada subjek IJ dan RA sudah mampu melakukan semua indikator dengan baik, sedangkan SY masih ada dua indikator yang belum mampu dilakukan pada indikator meniti di atas papan yang 
cukup lebar dan meniru gerakan senam sederhana seperti menirukan gerakan pohon, kelinci melompat. Sedangkan untuk aspek fisik motorik halus, berdasarkan hasil penelitian dari ketiga subjek didapatkan gambaran yaitu subjek IJ dan RA sudah mampu melakukan semua indikator dengan baik, sedangkan SY masih ada dua indikator yang belum mampu dilakukan pada indikator meronce benda yang cukup besar dan menggunting kertas mengikuti pola garis lurus.

Ada sembilan indikator yang menunjang perkembangan motorik anak terkait kesehatan dan perilaku keselamatan yaitu: (1) berat badan sesuai tingkat usia; (2) tinggi badan sesuai tingkat usia; (3) berat badan sesuai dengan standar tinggi badan; (4) lingkar kepala sesuai tingkat usia; (5) membersihkan kotoran (ingus); (6) menggosok gigi; (7) memahami arti warna lampu lalu lintas; (8) mengelap tangan dan muka sendiri; (9) memahami kalau berjalan di sebelah kiri. Dari kesembilan indikator tersebut dapat diperoleh gambaran bahwa ketiga subjek (IJ, RA, dan SY) masih ada beberapa indikator yang belum memenuhi atau belum tercapai, seperti tinggi badan sesuai tingkat usia, berat badan sesuai dengan standar tinggi badan, lingkar kepala sesuai tingkat usia, serta memahami arti warna lampu lalu lintas.

Hasil penelitian dari aspek perkembangan fisik motorik, ketiga subjek sudah mampu melakukan beberapa indikator dengan baik meskipun masih ada beberapa indikator yang belum tercapai. Keberhasilan dari tercapainya perkembangan anak karena stimulasi yang diberikan oleh orang tua dan kebebasan ruang gerak kepada anak untuk mencoba sesuatu yang baru. Selain dari stimulasi yang tepat, pemberian gizi seimbang juga sangat berpengaruh terhadap pertumbuhan dan perkembangan fisik motorik anak.

Stimulasi adalah perangsangan (penglihatan. Bicara, pendengaran, perabaan) yang datang dari lingkungan anak. Anak yang mendapat stimulasi yang terarah akan lebih cepat berkembang dibandingkan anak yang kurang bahkan tidak mendapat stimulasi (Kania, 2006: 4). Beberapa sikap yang bisa dikembangkan orangtua untuk mestimulasi perkembangan motorik anak, di antaranya : (1) memberikan kesempatan belajar anak untuk mempelajari kemampuan motoriknya, agar ia tak mengalami kelambatan perkembangan, (2) memberikan kesempatan mencoba seluas-luasnya agar ia bisa menguasai kemampuan motoriknya, (3) memberikan contoh yang baik, karena mempelajari dan mengembangkan kemampuan motoriknya lewat cara meniru, sikecil perlu mendapat contoh (model) yang tepat dan baik, (4) memberikan bimbingan karena meniru tanpa bimbingan tak akan mendapatkan hasil optimal. Ini penting agar ia mengenali kesalahannya, (5) penggunaan Kartu Menuju Sehat (KMS) yang bisa memantau perkembangan motorik anak secara praktis, untuk melihat apakah anak berkembang sesuai dengan tahapannya atau tidak (Indrijati, 2016: 35).

Selain pemberian stimulasi, Gizi merupakan faktor penting dalam proses tumbuh kembang fisik anak yang sedang tumbuh dan berkembang. Menurut Auliana (2011), Zat gizi dari makanan merupakan sumber utama untuk memenuhi 
kebutuhan anak tumbuh kembang optimal sehingga dapat mencapai kesehatan yang paripurna, yaitu sehat fisik, sehat mental, dan sehat sosial. Oleh karena itu, slogan umum bahwa pencegahan adalah upaya terbaik dan lebih efektif-efisien daripada pengobatan, harus benar-benar dilaksanakan untuk mencegah terjadinya masalah gizi pada anak. Hal ini pula menjadi tujuan utama Millinnium Development Goals (MDGs) tahun 2015 yang dicanangkan UNICEF: tercapainya keadaan gizi dan kesehatan yang baik serta seimbang.

\section{Aspek Perkembangan Kognitif}

Tingkat pencapaian perkembangan anak dalam aspek perkembangan kognitif dapat dilihat dari sepuluh indikator untuk belajar dan pemecahan masalah yaitu; (1) paham bila ada bagian yang hilang dari suatu pola gambar wajah orang matanya tidak ada, mobil bannya copot; (2) menyebutkan berbagai makanan dan rasanya (garam, gula atau cabai); (3) menyebutkan berbagai macam kegunaan dari benda; (4) memahami persamaan antara dua benda; (5) memahami perbedaan antara dua hal dari jenis yang sama seperti membedakan antara buah rambutan dan pisang; perbedaan antara ayam dan kucing; (6) bereksperimen dengan bahan menggunakan cara baru; (7) mengerjakan tugas sampai selesai; (8) menjawab apa yang akan terjadi selanjutnya dari berbagai kemungkinan; (9) menyebutkan bilangan angka 10; (10) mengenal beberapa huruf atau abjad tertentu dari A-Z yang pernah dilihanya. Pada aspek perkembangan berpikir logis terdapat lima indikator yaitu; (1) menempatkan benda dalam urutan ukuran (paling kecil-paling besar); (2) mulai mengikuti pola tepuk tangan; (3) mengenal konsep banyak dan sedikit; (4) mengenali alasan mengapa ada sesuatu yang tidak masuk dalam kelompok tertentu; (5) menjelaskan model atau karya yang dibuatnya. Kemudian pada aspek perkembangan untuk berpikir simbolik ada tiga indikator pencapaian yaitu; (1) menyebutkan peran dan tugasnya (missal, koki tugasnya memasak); (2) menggambarkan atau membentuk sesuatu konstruksi yang mendeskripsikan sesuatu yang spesifik; (3) melakukan aktivitas bersama teman dengan terencana (bermain berkelompok dengan memainkan peran tertentu seperti yang telah direncanakan).

Berdasarkan hasil penelitian untuk belajar dan pemecahan masalah sebagai berikut: IJ masih ada dua indikator yang belum tercapai yaitu bereksperimen dengan bahan menggunakan cara baru dan mengerjakan tugas sampai selesai, RA masih ada empat indikator yang belum tercapai dengan baik yaitu paham bila ada bagian yang hilang dari suatu pola gambar, bereksperimen dengan bahan menggunakan cara baru, mengerjakan tugas sampai selesai dan menjawab apa yang akan terjadi selanjutnya dari berbagai kemungkinan, sedangkan SY masih ada tiga indikator yang belum mampu dilakukan yaitu, memahami persamaan antara dua benda, berkesperimen dengan bahan menggunakan cara baru, dan menjawab apa yang akan terjadi selanjutnya dari berbagai kemungkinan 
Untuk berpikir logis, dari ketiga subjek masing-masing memiliki dua indikator yang belum mampu mereka lakukan, sebagai berikut: IJ dan Ra indikator yang belum tercapai yaitu mengenali alasan mengapa ada sesuatu yang tidak masuk dalam kelompok tertentu dan menjelaskan model/karya yang dibuatnya, sedangkan SY indikator yang belum tercapai yaitu menempatkan benda dalam urutan ukuran paling kecil- paling besar. Untuk berpikir simbolik, dari ketiga subjek hanya IJ yang sudah mampu melakukan semua indikator dengan baik, RA masih ada satu indikator yang belum tercapai yaitu menggambar atau membentuk sesuatu konstruksi yang mendeskripsikan sesuatu yang spesifik, sedangkan SY belum ada indikator yang mampu dilakukan.

Berdasarkan hasil penelitian dari aspek perkembangan kognitif, ketiga subjek masih banyak indikator yang belum tercapai, salah satu contohnya yaitu dapat dilihat dari indikator mengerjakan tugas sampai selesai yang dimana saat ketiga subjek diberi tugas tidak ada yang bisa menyelesaikannya. Hal ini disebabkan karena kurangnya kesadaran orang tua dalam menstimulasi anak terkait dengan indikator pencapaian yang terdapat paa aspek perkembangan kognitif yang menyebabkan perkembangan anak menjadi lambat.

Peran orang tua terhadap perkembangan anak dijelaskan oleh Darling dalam Thalib bahwa pengasuhan orang tua memberikan kontribusi utama terhadap proses sosialisasi anak, independensi, kematangan, kontrol diri, kemandirian, keingintahuan, persahabatan, orientasi berprestasi dan nilai-nilai prososial (Khadijah, 2016: 46-47). Menurut Ansori (2003:44) intervensi yang paling penting dilakukan oleh keluarga atau orang tua adalah memberikan pengalaman kepada anak dalam berbagai bidang kehidupan sehingga anak memiliki informasi yang banyak yang merupakan alat bagi anak untuk berfikir. Cara-cara yang digunakan misalnya memberikan kesempatan kepada anak untuk merealisasikan ide-idenya, menghargai ide-ide tersebut, memuaskan dorongan ingin tahu anak dengan jalan seperti menyediakan bacaan alat-alat keterampilan dan alat-alat yang dapat mengembangkan daya kreativitas anak (Khadijah, 2016: 46-47). Adapun yang menunjukkan bahwa bermain merupakan salah satu cara sikecil mempelajari kemampuan pemecahan masalah anak yaitu Neuroscience. Kegiatan bermain yang dapat dilakukan untuk mengembangkan kemampuan kognitif anak dengan menggunakan metode pemecahan masalah diantaranya, bermain balok, bermain peran, bermain labirin dan menyusun balok dengan kubus. Sebagai contoh, saat anak bermain labirin, disini anak dilatih untuk memecahkan masalah dalam mencari jalan keluar serta melatih anak tentang cara berfikir dan kreatifitas anak (Utami, dkk 2017:179-180).

\section{Aspek Perkembangan Bahasa}

Pada tahapan pencapaian perkembangan bahasa pada anak dapat dilihat dua indikator pada bagian untuk memahami bahasa yaitu: (1) Pura-pura membaca cerita 
bergambar dalam buku dengan kata-kata sendiri; (2) mulai memahami dua perintah yang diberikan bersamaan contoh: ambil mainan diatas meja lalu berikan kepada ibu pengasuh atau pendidik. Sedangkan pada bagian untuk mengungkapkan bahasa terdapat dua indikator yaitu: (1) mulai menyatakan keinginan dengan mengucapkan kalimat sederhana (6 kata); (2) mulai menceritakan pengalaman yang dialami dengan cerita sederhana.

Berdasarkan hasil penelitian dari aspek perkembangan bahasa, dari ketiga subjek sudah mampu melakukan semua indikator yaitu pada bagian memahami bahasa dan mengungkapkan bahasa dengan sangat baik. Hal ini disebabkan karena karena peran orang tua dalam menstimulasi tingkat pencapaian di setiap indikator anak dikontrol dengan baik. Seperti anak sering diminta untuk bercerita tentang pengalamannya atau apa saja yang ia lakukan.

Menurut Epstein (2001) peran orangtua dalam mengembangkan bahasa anak diklasifikasikan menjadi enam jenis keterlibatan orang tua, meliputi parenting (pengasuhan), communication (komunikasi), volunteering (sukarela), learning at home (belajar di ruma), decision making (pengambilan keputusan), dan collaborating with the community (kolaborasi dengan keluarga/masyarakat). Keterlibatan orang tua yang pertama yaitu parenting (pengasuhan). Dalam poin ini, tujuannya adalah membentuk lingkungan keluarga ibarat sekolah, jadi orang tua harus mendukung anak-anak sebagai siswa. Jika dia membuat kesalahan, maka orang tua harus mengarahkan. Orang tua juga harus mengajar dan mendidik anak agar menjadi anak yang baik dan berpotensi. Keterlibatan kedua yaitu communication (komunikasi). Tujuan dari keterlibatan ini adalah merancang bentuk komunikasi yang efektif dari sekolah ke rumah dan komunikasi dari rumah ke sekolah sehingga mengetahui program sekolah dan kemajuan anak-anak mereka. Selanjutnya, tujuan dari volunteering (sukarela) adalah mengatur bantuan dan dukungan orang tua. Keterlibatan learning at home (belajar di rumah) memiliki tujuan memberikan informasi dan gagasan kepada keluarga tentang bagaimana caranya membantu anak belajar di rumah, yaitu bagaimana cara membuat rencana kegiatan, mengaplikasikan dan mengevaluasi. Dan yang terakhir collaborating with the community (kolaborasi dengan keluarga/masyarakat). Dalam poin terakhir ini, orang tua harus mengidentifikasi dan mengintegrasikan sumber daya dan layanan dari masyarakat untuk memperkuat program sekolah, praktik keluarga, pembelajaran serta pengembangan siswa (Sucita, 2017: 369).

\section{Aspek Perkembangan Sosial Emosional}

Pada tahapan perkembangan social emosional, terdiri dari tingkat kesadaran diri, tanggung jawab diri dan orang tua dan perilaku prososial. Untuk perkembangan kesadaran diri, terdapat empat indicator pencapaian yaitu: (1) mengikuti aktivitas dalam suatu kegiatan besar, misalnya pikni; (2) meniru apa yang dilakukan orang dewasa; (3) bereaksi terhadap hal-hal yang tidak benar, misalnya marah bila 
diganggu; (4) mengatakan perasaan secara verbal. Selanjutnya perkembangan tanggung jawab diri dan orang tua terdapat lima indicator pencapaian perkembangan yaitu: (1) mulai bias melakukan buang air kecil tanpa bantuan; (2) bersabar menunggu giliran; (3) mulai menunjukkan sikap toleran sehingga dapat bekerja dalam kelompok; (4) mulai menghargai orang lain; (5) mulai menunjukkan ekspersi menyesal ketika melakukan kesalahan. Pada perkembangan Perilaku prososial terdapat tiga indikator pencapaian perkembangan yaitu: (1) membangun kerjasama; (2) memahami adanya perbedaan perasaan, misalnya teman takut, saya tidak; (3) meminjam dan meminjamkan mainan.

Dari hasil penelitian pada aspek perkembangan sosial emosional dapat digambarkan sebagai berikut: Untuk bagian kesadaran diri, ketiga subjek sudah mampu melakukan semua indikator dengan baik. Untuk bagian tanggung jawab diri dan orang lain, IJ masih ada satu indikator yang belum mampu dilakukan yaitu indikator bersabar menunggu giliran, RA masih ada satu indikator yang belum mampu dilakukan yaitu mulai menunjukkan sikap toleran sehingga dapat bekerja dalam kelompok, sedangkan SY masih ada empat indikator yang belum mampu dia lakukan yaitu mulai bisa melakukan buang air kecil tanpa bantuan, bersabar menunggu giliran, mulai menunjukkan sikap toleran sehingga dapat bekerja dalam kelompok, dan mulai menghargai orang lain. Hal ini disebabkan karena SY terlalu dimanja oleh orang tuanya, kurangnya penjelasan dan bimbingan kepada anak tentang bagaimana membangun kerja sama terhadap orang lain. Kemudian untuk bagian perilaku sosial, dari ketiga subjek hanya IJ yang mampu melakukan semua indikator dengan baik, RA masih ada satu indikator yang belum mampu dilakukan yaitu meminjam dan meminjamkan mainan, sedangkan SY masih ada satu indikator juga yang belum mampu dilakukan yaitu membangun kerjasama.

Peran aktif orang tua terhadap perkembangan anak-anaknya sangat diperlukan karena pendidikan pertama dan paling utama didapatkan dari orangtua atau keluarga terutama pada saat mereka masih berada dibawah usia lima tahun (balita). Dalam usaha mendidik anak harus diperhatikan pula adanya peran aktif dari segi anak itu sendiri. Anak harus lebih diperlakukan sebagai pribadi anak yang aktif yang perlu dirangsang (stimulasi) untuk menghadapi dan mampu mengatasi masalah. Melalui interaksi dan komunikasi antara orang tua dan anak, maka akan berkembang berbagai aspek kepribadian anak termasuk aspek kesadaran terhadap tanggung jawab. (Suherman, 2000)

Menurut Boyd (Soetjininingsih 2012: 214), orang tua atau keluarga, guru dan teman sebaya sangat berperan dalam pencapaian perkembangan sosial emosional yang baik pada masa kanak-kanak. Berikut merupakan faktor yang mempengaruhi perkembangan sosial emosional anak usia dini adalah: Pertama peran keluarga, salah satu faktor dalam keluarga yang mempengaruhi perkembangan sosial emosional pada anak adalah bagaimana pola asuh orangtuanya. Ada beberapa pola asuh yang ditunjukkan oleh para orangtua yang dapat mempengaruhi 
perkembangan sosial emosional pada anak, antara lain (1) Pola Asuh otoriter yaitu pola asuh yang ditandai dengan pembatasan, menghukum, memaksa anak mengikuti aturan, dan kontrol yang ketat; (2) Pola asuh Otoriatif atau Demokratis, yaitu pola asuh yang mendorong anak mandiri tetapi masih menetapkan batasanbatasan dan pengendalian dan tindakan anak; (3) Pola asuh yang Membiarkan, merupaka gaya pengasuhan yang mana orangtua sangat terlibat dalam kehidupan anak tetapi tidak menetapkan batasan sedikit batasan, tidak terlalu menuntut, dan tidak mengontrol mereka; (4) pola asuh yang mengabaikan, yaitu pola asuh dimana orang tua sangat tidak terlibat dalam kehidupan anak. Dari keempat pola asuh yang diterapkan keluarga untuk meningkatkan perkembangan sosial emosional anak usia dini, terdapat satu pola asuh yang sangat baik diterapkan untuk membuat perkembangan sosial emosional anak usia dini meningkat yaitu pola asuh otoritatif atau pola asuh demokratis. Kedua Relasi dengan teman sebaya, pada masa kanakkanak awal, hubungan dengan teman sebaya makin meningkat dan menghabiskan banyak waktunya. Salah satu fungsi terpenting dari teman sebaya adalah sebagai sumber informasi dan bahan pembanding di luar lingkungan keluarga. Melalui teman sebaya, anak memperoleh umpan balik tentang kemampuannya, mengevaluasi apa yang mereka lakukan dibanding teman sebayanya. Hubungan yang baik dengan teman sebaya sangat penting bagi perkembangan sosial emosional anak yang baik (Islamiyati, 2018: 22).

\section{Aspek Perkembangan Seni}

Pada tahapan pencapaian perkembangan seni pada anak terdiri dari tiga bagian yaitu anak mampu membedakan bunyi dan suara, tertarik dengan kegiatan musik, gerakan orang, hewan maupun tumbuhan, dan Tertarik dengan kegiatan atau karya seni. Untuk tingkat pencapaian mampu membedakan bunyi dan suara, terdapat dua indikator yaitu: (1) mengenali berbagai macam suara dari kendaraan; (2) meminta untuk didengarkan lagu favorit secara berulang. Pada tingkat pencapaian tertarik dengan kegiatan musik, gerakan orang, hewan maupun tumbuhan terdapat lima indikator pencapaian, yaitu: (1) mendengarkan atau menyanyikan lagu; (2) menggerakkan tubuh sesuai irama; (3) bertepuk tangan sesuai irama musik; (4) meniru aktivitas orang, baik secara langsung maupun melalui media, misal cara minum/cara bicara/perilaku seperti ibu; (5) bertepuk tangan dengan pola yang berirama, misalnya bertepuk tangan sambil mengikuti irama/nyanyian. Serta pada tingkat pencapaian tertarik dengan kegiatan atau karya seni, terdapat tiga indikator pencapaian yaitu: (1) menggambar dengan menggunakan beragam media seperti cat air, spidol, serta dengan cara seperti finger painting, cat air dll; (2) membentuk sesuatu dengan plastisin; (3) mengamati dan membedakan benda di sekitarnya yang di luar rumah.

Berdasarkan hasil penelitian terkait perkembangan seni dapat digambarkan sebagai berikut: pada bagian mampu membedakan antara bunyi dan suara, dua 
subjek IJ dan SY sudah mampu melakukan semua indikator dengan baik, sedangkan RA masih ada satu indikator yang belum mampu dia lakukan yaitu meminta untuk diperdengarkan lagu favorit secara berulang. Pada bagian tertarik dengan kegiatan musik, gerakan orang, hewan dan tumbuhan, ketiga subjek IJ, RA, SY sudah mampu melakukan semua indikator dengan baik. Hal ini disebabkan karena stimulasi yang tepat diberikan oleh orang tua. Kemudian pada bagian tertarik dengan kegiatan atau karya seni, dua subjek IJ dan SY sudah mampu melakukan semua indikator dengan baik. Hal ini disebabkan karena orang tua sering memberikan stimulasi seperti memberikan contoh menggambar dengan menggunakan berbagai media (spidol, pensil warna), membentuk sesuatu dengan plastisin. Sedangkan RA masih ada satu indikator yang belum mampu dia lakukan yaitu menggambar dengan menggunakan beragam media (cat air, spidol, alat menggambar) dan cara (finger painting, cat air). Hal ini sebabkan karena anak kurang diberikan stimulasi oleh orang tuanya dan anak lebih banyak dikasih gadget untuk bermain.

Strategi atau cara yang dapat dilakukan untuk mengembangkan kreativitas pada anak yaitu dengam membiarkan anak untuk bereksplorasi, tidak membatasi anak, menyediakan sarana dalam hal ini permainan yang dapat mengembangkan kemampuan seni anak. Terdapat tujuh strategi pengembangan pada anak usia dini, yaitu (1) Pengembangan kreativitas melalui menciptakan produk melalui hasil karya; (2) Pengembangan Kreativitas melalui Imajinasi; (3) Pengembangan Kreativitas melalui Eksplorasi; (4) Pengembangan Kreativitas melalui Eksperimen; (5) Pengembangan Kreativitas melalui Proyek; (6) Pengembangan Kreativitas melalui Musik; (7) Pengembangan Kreativitas melalui Bahasa (Rachmawati Yeni \& Kurniati Euis, 2011)

Berhasil atau tidaknya dalam pencapaian indikator tersebut didasarkan pada beberapa faktor yaitu pola asuh yang otoriter, terlalu membatasi anak dalam melakukan sesuatu, kurangnya sarana bermain serta kurangnya alat permainan yang tersedia. Perkembangan aspek seni pada anak sangat erat kaitanya dengan kreativitas pada anak, perkembangan seni pada anak bukan tentang bagaimana anak mampu melakukan semua hal-hal yang berkaitan dengan seni, tetapi agar bagaimana kreativitas pada anak dapat berkembang sejak dini. Pentingnya mengembangkan seni pada anak didasarkan pada agar bagaimana anak mampu mengintegrasikan keterampilan seni yang ada pada dirinya, membantu anak mengekspresikan dirinya melalui imajinasinya, mengembangkan potensi diri yang dimiliki anak, mengembangkan bakat yang dimilinya, seperti bernyanyi, menari, menggambar dan sebagainya.

\section{SIMPULAN}

Penelitian ini menggambarkan deskripsi tingkat pencapaian perkembangan ketiga subjek penelitian mulai dari aspek agama-moral, fisik-motorik, kognitif, bahasa, sosial-emosional, seni. Perkembangan agama-moral, ketiga subjek sudah 
mampu mengenal ciptaan Tuhan, meniru doa pendek dan memahami perilaku baikburuk, benar-salah, sopan-tidak sopan. Perkembangan fisik motorik, untuk bagian motorik kasar ada dua subjek IJ dan RA sudah mampu melakukan semua indikator dengan baik, sedangkan SY masih ada dua indikator yang belum mampu dilakukan. Untuk bagian motorik halus ada dua subjek IJ dan RA sudah mampu melakukan semua indikator dengan baik, sedangkan SY masih ada dua indikator yang belum mampu dilakukan. Untuk bagian kesehatan dan perilaku keselamatan, dari ketiga subjek masih ada beberapa indikator yang belum memenuhi atau tercapai. Pada perkembangan bahasa, untuk bagian memahami bahasa ketiga subjek sudah mampu melakukan semua indikator dengan baik. Untuk bagian mengungkapkan bahasa, dari ketiga subjek sudah mampu melakukan semua indikator dengan baik. Perkembangan social emosional, untuk bagian kesadaran diri ketiga subjek sudah mampu melakukan semua indikator dengan baik. Untuk bagian tanggung jawab diri dan orang lain, dua subjek IJ dan RA masing-masing memiliki satu indikator yang belum mampu dilakukan, sedangkan SY masih ada empat indikator yang belum mampu dilakukan. Untuk bagian perilaku prososial, ketiga subjek hanya satu subjek IJ yang sudah mampu melakukan semua indikator dengan baik, sedangkan RA dan SY masing-masing ada satu indikator yang belum mampu dilakukan. Perkembangan seni, untuk bagian anak mampu membedakan antara bunyi dan suara dari tiga subjek dua subjek diantaranya IJ dan SY sudah mampu melakukan semua indikator dengan baik, sedangkan RA masih ada satu indikator yang belum mampu dilakukan. Untuk bagian tertarik dengan kegiatan music, gerakan orang, hewan dan tumbuhan, ketiga subjek sudah mampu melakukan semua indikator dengan dengan baik. Sedangkan untuk bagian tertarik dengan kegiataan atau karya seni, dari tiga subjek hanya dua subjek IJ dan SY sudah mampu melakukan semua indikator dengan baik, sedangkan RA masih ada satu indikator yang belum mampu dilakukan. Keberhasilan dari tingkat pencapaian anak disebabkan karena polah asuh orang tua yang sangat baik dan pemberian stimulus dalam setiap aspek perkembangan anak serta dukungan dan motovasi yang besar dari lingkungan sekitar.

\section{DAFTAR PUSTAKA}

Ananda, Rizki. (2017). Implementasi Nilai-Nilai Moral dan Agama Pada Anak Usia Dini. Jurnal Obsesi: Jurnal Pendidikan Anak Usia Dini. Vol. 1. No.1. Universitas Pahlawan Tuanku Tambusai.

Hulukati, Wenny. (2015). Peran Keluarga Terhadap Perkembangan Anak. Jurnal MUSAWA. Vol. 7 No. 2

Indrijati, Herdina. (2016). Psikologi Perkembangan \& Pendidikan Anak Usia Dini Sebuah Bunga Rampai. Jakarta. Kencana 
Islamiyah, Dina. (2018). Upaya Peningkatan Perkembangan Sosial Emosional Anak Usia Dini Melalui Metode Bermain Peran Bagi Siswa Kelompok B TK Pertiwi 3 Pulutan Nogosari Boyolali. Skripsi Surakarta. Institut Afama Islam Negeri Surakarta

Khadijah. (2016). Pengembangan Kognitif Anak Usia Dini. Medan. Perdana Publishing.

Khaironi, Mulianah. (2017). Pendidikan Moral Pada Anak Usia Dini. Jurnal Golden Age. Vol. 1. No.1. Universitas Hamzanwadi

Rachmawati, Yeni dan Kurniati Euis. (2010). Strategi Pengembangan Kreativitas Pada Anak Usia Taman Kanak-Kanak. Jakarta. Kencana

Sit, Masganti. (2017). Psikologi Perkembangan Anak Usia Dini. Cimanggis, Depok. Kencana

Sucita. (2017). Peran Orang Tua Dalam Pengembangan Bahasa Anak Usia Dini. Jurnal STAIN Kudus. Vol. 5. No. 2.

Suharmini, Tin, Fatimaningrum Arumi Savitri, Mahabbati, Aini. (2009). Pelatihan Karakteristik dan Deteksi Tumbuh Kembang Anak Usia Dini Bagi Kader Posyandu Plus. Jurnal INOTEK Inovasi dan Aplikasi Teknologi. Vol. 13. No. 2

Supartini, Yupi. (2004). Konsep Dasar Keperawatan Anak. Jakarta: Penerbit Buku Kedokteran EGC.

Susanto, Ahmad. (2011). Perkembangan Anak Usia Dini Pengantar dalam Berbagai Aspeknya. Jakarta. Kencana 